УДК 619:616-053.31:636.3

(C) 2013

Скляров П. М., кандидат сільськогосподарських наук

Дніпропетровський державний аграрний університет

\title{
ВПЛИВ ВІТАМІНУ А НА МОРФОЛОГІЧНИЙ СТАН ПЛАЦЕНТИ І ПЛОДА У КІЗ
}

\section{Рецензент - кандидат ветеринарних наук Л. В. Корейба}

У плачентах тварин із дефіциитом вітаміну А спостерігалися морфологічні та функиіональні зміни, порушення їі структури, атрофія і руйнування кінщевих ворсин, дистрофія й десквамація епітелію ворсин. Крім иього, була меншою кількість котиледонів (на 8,2\%), нижчими -маса посліду (на

18,6\%), площа ворсинчастого хоріону (на 21,7\%), а також достовірно вищими: маса тіла (на 14,9\%) та органів - серия (на 6,7\%), легень (на 5,6\%), шлунка з китечником (на 14,4\%), печінки (на 23,9\%), нирок (на 7,8-10,1\%), селезінки (на 29,2\%), мозку (на 11,4\%), надниркових залоз (на 17,7\%), щүитовидної залози (24,4\%), матки з яєчниками (на 6,4\%).

Ключові слова: антенатальна гіпотрофія, ягнята, козенята, плід, плацента.

Постановка проблеми. Успішний розвиток тваринництва здебільшого залежить від одержання і вирощування здорового молодняку й $€$ однією $з$ найважливіших і складних задач. Адже 3 усіх видів втрат у тваринництві найбільшу питому вагу займають незаразні хвороби молодняку. Найбільш масово і важко, зі значним відходом хворіє молодняк у пору новонародженості.

Однією з причин, що гальмують повне збереження новонародженого молодняку, $є$ гіпотрофія новонароджених тварин. Ця патологія має широку розповсюдженість у господарствах, де не приділяють належної уваги правильній годівлі та утриманню вагітних тварин. Гіпотрофія новонароджених спричиняє значний економічний збиток та викликає великий відхід молодняку [1].

Аналіз основних досліджень і публікацій, у яких започатковано розв'язання проблеми. Гіпотрофія ягнят та козенят - це загальносистемне захворювання новонароджених, що $\epsilon$ наслідком порушень розвитку плода i $є$ поширеною патологією у вівчарстві й козівництві, завдає значних економічних збитків, скорочуючи потенціальні можливості розвитку галузей. Адже гіпотрофіки мають знижену життєздатність, погано розвиваються, у них низький приріст маси тіла, $\mathrm{i}$, як правило, перехворюють гастроентеральними і респіраторними захворюван- нями зі значною летальністю [6-7]. Новонароджені ягнята та козенята 3 гіпотрофією виділяються у групу високого ризику смерті, захворювань і вірогідності затримки фізіологічного розвитку у подальшому.

Провідними причинами виникнення антенатальної гіпотрофії плода $\epsilon$ порушення функціонування фето-плацентарного комплексу [2-3]. Фето-плацентарна недостатність є однією 3 провідних причин високого ризику вагітності і родів, значного рівня перинатальних втрат, виражених відхилень у розвитку новонароджених [8-9].

Незважаючи на значні успіхи сучасної перинатології, антенатальна гіпотрофія залишається однією з головних причин перинатальної захворюваності та смертності.

Мета роботи - дослідження розвитку плаценти й плода у кіз залежно від рівня естрогенів та забезпеченості вітаміном А, які є основними етіологічними чинниками антенатальної гіпотрофії [1].

Матеріал і методи досліджень. Об'єктом досліджень були плаценти і плоди кіз віварію кафедри акушерства ХДЗВА та приватного сектору Малоданилівської селищної ради. При дослідженні плаценти визначали масу посліду, кількість котиледонів, площу кожного котиледона та загальну площу ворсинчастого хоріону. Було сформовано дві групи кіз (по 3 тварини у кожній). Тварин відбирали за принципом аналогів: порода аборигенна, вік 3-5 років, маса 39-47 кг. Утримання - у пристосованому приміщенні. Раціон тварин дослідної групи був повноцінним за поживними речовинами, вітамінами, макро- і мікроелементами, у контрольній групі - неповноцінний за каротином. Дослідження вагітних самок проводили використовуючи загальні клінічні і вагінальні методи. Визначення біохімічних показників крові (загальний білок, неорганічний кальцій, неорганічний фосфор, вітамін А у сироватці) - згідно із загальноприйнятими методиками. Розміри плодів, їх органів і плаценти визначали за допомогою сантиметра, масу - 3 використанням електронних терезів Aurora - Electronic kitchen scale AU 313. 

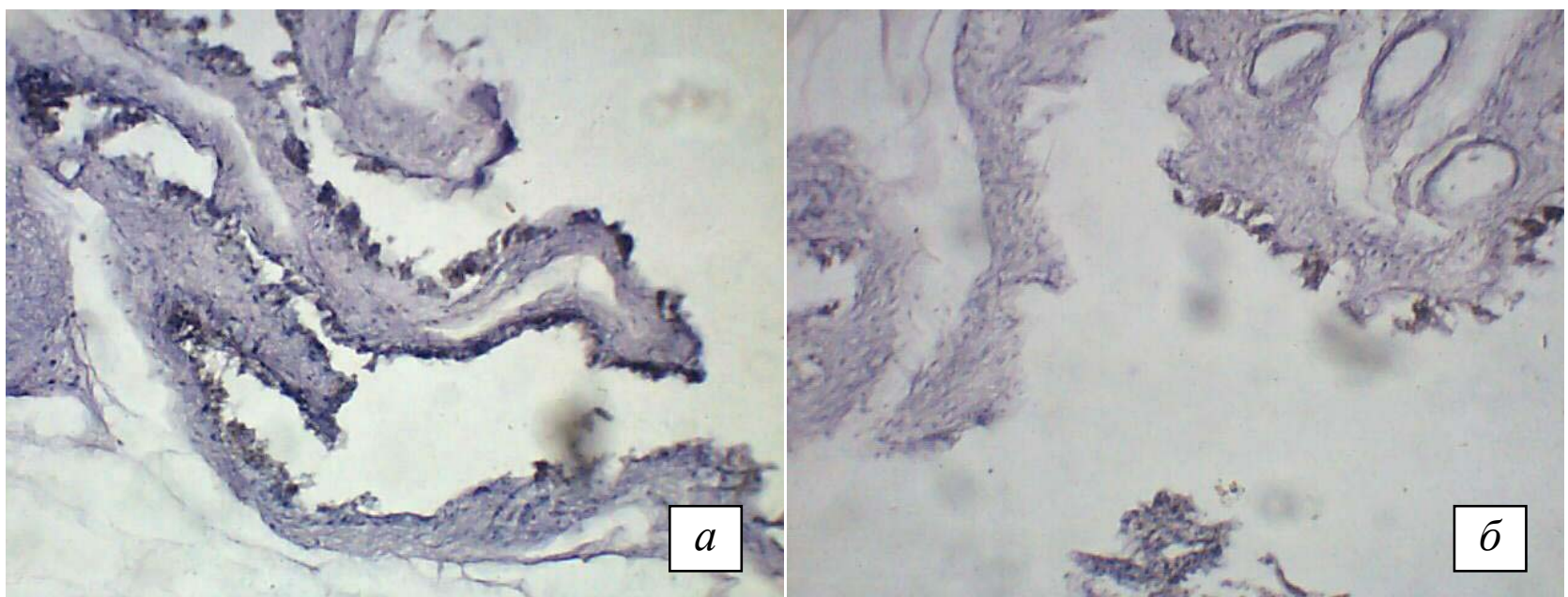

Рис. Гістопрепарат фетальної плаценти кози: а) з нормальними показниками гомеостазу; б) з А-вітамінною недостатністю (гематоксилін і еозин, ×400)

Результати досліджень. У попередніх дослідженнях нами визначено залежність маси плода овець від вагових та морфологічних показників плаценти при А-вітамінній недостатності. Встановлено, що дефіцит вітаміну А в організмі зумовлює плацентарну недостатність і негативно впливає на розвиток і масу плода овець [4].

Крім того, нами встановлено позитивний корелятивний зв'язок між рівнем естрогенів та розвитком плода [5].

Основну увагу при проведенні цього дослідження було приділено визначенню впливу ві- таміну А на масу плодів у цілому, абсолютну та відносну масу їх органів та морфофункціональні зміни у таких органах, як плацента (хоріальна частина), щитоподібна залоза, печінка, надниркові залози, матка, яєчники плодів.

За станом плаценти при родах можна судити про ступінь розвитку новонародженого. У цілому ж розміри плаценти, iii васкуляризація, ступінь формування ворсин тісно пов'язані з розвитком плода та визначаються потребою його у поживних речовинах, у зв'язку з чим виникає необхідність своєчасної та правильної оцінки стану цього органа.

\section{1. Морфологічна характеристика плаценти кіз дослідної та контрольної груп}

\begin{tabular}{|c|c|c|c|}
\hline \multirow{2}{*}{ Показники } & \multicolumn{2}{|c|}{ Групи тварин } & \multirow{2}{*}{$\%$} \\
\cline { 2 - 3 } & контрольна $(\mathrm{n}=3)$ & дослідна $(\mathrm{n}=3)$ & \\
\hline Кількість котиледонів, шт. & $96,67 \pm 4,10$ & $89,33 \pm 3,18$ & 8,2 \\
\hline Маса плідної плаценти (посліду), г & $301,67 \pm 28,49$ & $254,33 \pm 37,23$ & 18,6 \\
\hline Площа ворсинчастого хоріону, $\mathrm{cm}^{2}$ & $398,73 \pm 25,36$ & $327,56 \pm 28,70$ & 21,7 \\
\hline
\end{tabular}

2. Маса плодів та їх органів у тварин контрольної та дослідної груп

\begin{tabular}{|c|c|c|c|c|c|c|c|c|c|c|c|c|}
\hline \multirow{3}{*}{$\begin{array}{c}\text { Група } \\
\text { тварин }\end{array}$} & \multicolumn{12}{|c|}{ Maca } \\
\hline & \multirow{2}{*}{$\begin{array}{l}\text { 它 } \\
\text { 章 } \\
\text { 官 }\end{array}$} & \multirow{2}{*}{$\begin{array}{l}\text { 岁 } \\
\text { 造 }\end{array}$} & \multirow{2}{*}{ 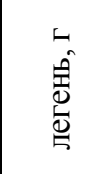 } & \multirow{2}{*}{ 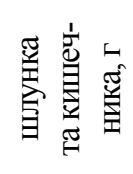 } & \multirow{2}{*}{ 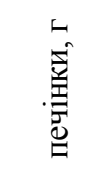 } & \multicolumn{2}{|c|}{ нирок, Г } & \multirow{2}{*}{ 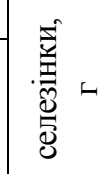 } & \multirow{2}{*}{ 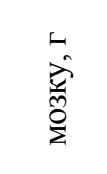 } & \multirow{2}{*}{ 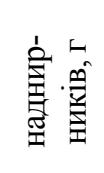 } & \multirow{2}{*}{ 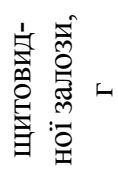 } & \multirow{2}{*}{ 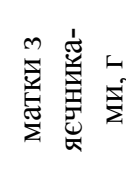 } \\
\hline & & & & & & лівої & правої & & & & & \\
\hline $\begin{array}{c}\text { Дослідна } \\
(\mathrm{n}=3)\end{array}$ & 2815,33 & 47,36 & 92,51 & 236,69 & 95,95 & 28,40 & 28,35 & 6,48 & 64,78 & 1,86 & 0,82 & 2,33 \\
\hline $\mathrm{M} \pm \mathrm{m}$ & 65,13 & 2,15 & 5,14 & 8,61 & 22 & 95 & 05 & 0,19 &, 33 & 08 & 0,04 & 0,08 \\
\hline $\begin{array}{c}\text { Контроль- } \\
\text { на }(\mathrm{n}=3)\end{array}$ & 5,67 & 44,19 & 87,32 & 202,47 & 73,04 & 26,19 & 25,49 & 4,59 & 57,39 & 1,53 & 0,62 & 2,18 \\
\hline $\mathrm{M} \pm \mathrm{m}$ & 74,87 & 1,78 & 4,25 & 10,40 & 4,54 & 1,59 & 1,79 & 0,11 & 1,73 & 0,09 & 0,06 & 0,06 \\
\hline \pm & $-419,66$ & $-3,17$ & $-5,19$ & $-34,22$ & $-22,91$ & $-2,21$ & $-2,86$ & $-1,89$ & $-7,39$ & $-0,33$ & $-0,20$ & $-0,15$ \\
\hline$\%$ & $-14,9$ & $-6,7$ & $-5,6$ & $-14,4$ & $-23,9$ & $-7,8$ & $-10,1$ & $-29,2$ & $-11,4$ & $-17,7$ & $-24,4$ & $-6,4$ \\
\hline $\mathrm{P}$ & $<0,999$ & $<0,95$ & $<0,95$ & $<0,95$ & $<0,999$ & $<0,95$ & $<0,999$ & $<0,999$ & $<0,999$ & $<0,99$ & $<0,95$ & $<0,95$ \\
\hline
\end{tabular}

Примітка: $\mathrm{P}<0,95$ - критерій низької вірогідності; $\mathrm{P}<0,99$ - критерій середньої вірогідності;

$\mathrm{P}<0,999$ - критерій високої вірогідності 
Характеристика плаценти овець контрольної і дослідної груп наведено у таблиці 1 .

У результаті досліджень встановлено, що досліджувані посліди не мали патологічних відхилень (змін кольору, нашарувань і т. ін.), були блискучі й добре васкуляризовані. Однак у плацентах із дефіцитом вітаміну А (контроль) спостерігалися морфологічні та функціональні зміни, порушення iї структури, атрофія і руйнування кінцевих ворсин, дистрофія і десквамація епітелію ворсин (див. рис.).

Порівняно $з$ контрольною групою у дослідній (дефіцит вітаміну А) була меншою кількість котиледонів (на 8,2\%), нижчими маса посліду (на $18,6 \%$ ), площа ворсинчастого хоріону (на 21,7 \%).

Дані таблиці 2 свідчать, що у тварин контрольної групи достовірно вищими були всі оцінювані параметри: маса тіла (на 14,9 \%) та органів - серця (на 6,7\%), легень (на 5,6\%), шлунка 3 кишечником (на 14,4 \%), печінки (на 23,9\%), нирок (на 7,8$10,1 \%$ ), селезінки (на $29,2 \%$ ), мозку (на $11,4 \%$ ), надниркових залоз (на 17,7 \%), щитовидної залози $(24,4 \%)$, матки 3 яєчниками (на $6,4 \%)$. Характеристику плодів та їх органів наведено у таблиці 2.

\section{БІБЛІОГРАФІЯ}

1. Ветеринарна перинатологія: навч. пос. для студ. вищ. навч. закл. / В. П. Кошовий [та ін.]; за заг. ред. В. П. Кошового. - Харків: Видавництво Шейніної О. В., 2008. - 465 с.

2. Дашкевич В. С. Плацентарна недостатність: сучасні аспекти патогенезу, діагностики, профілактики та лікування / В. С. Дашкевич // Мистецтво лікування. - 2004. - № 4. - С. 22-25.

3. Майоров М. В. Фетоплацентарная недостаточность: актуальные особенности патогенеза, диагностики и терапии [Электронный ресурс] / М.В.Майоров; женская консультация городской поликлиники № 5 г. Харькова // Провизор. 2005. - №3. - Режим доступа : http://www.provisor. com.ua/ archive/2005/N3/art_29.htm.

4. Скляров П. М. Особливості структури плаценти вівці при А-вітамінній недостатності / П. М. Скляров, В. П. Кошовий // Проблеми зооінженерії та ветеринарної медицини : зб. наук. праць ХДЗВА за матер. Міжнар. наук. конф. «Актуальные вопросы борьбы с инфекционными заболеваниями в гуманной и ветеринарной медицине», присв. 160-річчю 3 дня народження I. I. Мечнікова (м. Харків, 28-30 листопада 2005 р.). - Х. : РВВ ХДЗВА, 2006. Вип. 13 (33). - Ч. 2. - С. 240-243.

5. Скляров П. Н. Развитие плаценты и плода у
Висновки. Досліджувані посліди не мали патологічних відхилень (змін кольору, нашарувань $i$ т. ін.), були блискучими, добре васкуляризованими. Однак у плацентах тварин із дефіцитом вітаміну А спостерігалися морфологічні та функціональні зміни, порушення ії структури, атрофія i руйнування кінцевих ворсин, дистрофія і десквамація епітелію ворсин. Порівняно з контрольною групою у дослідній (дефіцит вітаміну А) була меншою кількість котиледонів (на 8,2 \%), нижчими маса посліду (на 18,6 \%), площа ворсинчастого хоріону (на 21,7\%), а також достовірно вищими: маса тіла (на $14,9 \%$ ) та органів серця (на 6,7\%), легень (на 5,6 \%), шлунка 3 кишечником (на 14,4\%), печінки (на 23,9\%), нирок (на 7,8-10,1\%), селезінки (на 29,2\%), мозку (на 11,4\%), надниркових залоз (на 17,7\%), щитовидної залози $(24,4 \%)$, матки 3 яєчниками (на $6,4 \%$ ).

Враховуючи результати даних та попередніх досліджень 3 вивчення механізмів розвитку антенатальної патології у овець і кіз, будуть розроблені заходи з профілактики даної патології.

овец и коз в зависимости от уровня эстрогенов / Скляров П. Н. // Бюл. науч. работ ФГОУ ВПО «Белгородская государственная с.-х. академия». Белгород, 2010. - №21: спецвыпуск, посв. 25-летию факультета ветеринарной медицины. C. 36-38.

6. Стадник A. M. Роль пренатальної гіпотрофії в етіології незаразних хвороб телят / А. М. Стадник // Наук. вісник Львівської державної академії ветеринарної медицини ім. С. З. Гжицького. Т. 4 (№5). - Львів, 2002. - С. 212-215.

7. Харута Г. Г. Гіпотрофія новонароджених телят / Харута Г. Г., Івасенко Б. П., Ордін Ю. М. // Ветеринарна медицина України. - 1997. - № 6. C. 28-29.

8. Чуб В. В. Фетоплацентарная дисфункция: основы патогенеза, проблемы диагностики, тактика лечения. Методические рекомендации / Чуб В. В., Чибисова И. В., Климов В. А. - Луганск, 2003. $36 \mathrm{c}$.

9. Штехина E. E. Структурная организация органов иммуногенеза плодов овец при нормальной беременности и при фетоплацентарной недостаточности : дис. ... канд. биол. наук : 16.00 .02 / Штехина Е. Е. - Ставрополь, 2005. - 125 с. 